\title{
Språket på spåret mellan Lund och Växjö
}

\section{Gunilla Byrman \& Jan Einarsson}

Utgångspunkten för denna text är språkliga betraktelser och reflektioner gjorda av två pendlare som färdats med tåg mellan Lund och Växjö. Stationerna på dessa två orter har på senare år genomgått omfattande förändringar.

Bild 1. Lunds östra station och Växjö station 2018
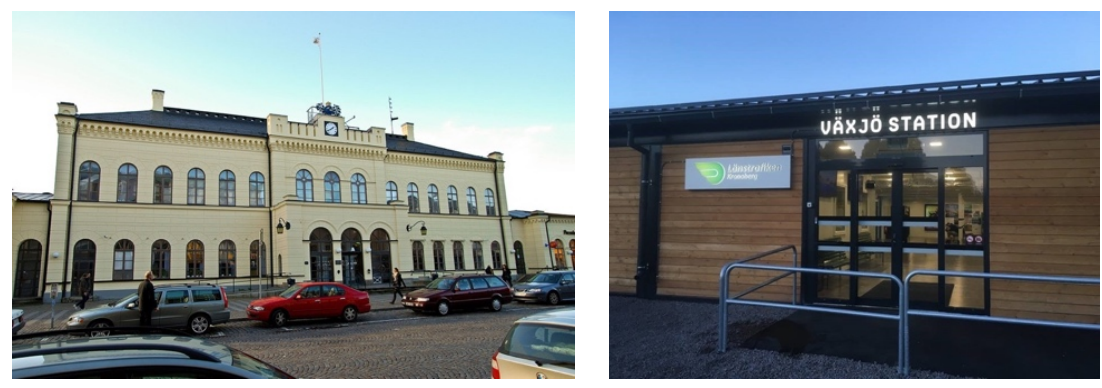

Vad kan pendlande språkforskare ägna sig åt för att hålla sig i lingvistisk trim under sina tågresor mellan Lund och Växjö? - De kan fundera över namnen på de orter som passeras, och de kan göra betraktelser över andra språkligheter som möter tågresenärerna.

När vi i vår ungdom började resa med tåg utgjordes personalen i personvagnarna av en uniformsklädd man med skärmmössa. Han var konduktör 'tågmästare, tågbefälhavare, biljettkontrollör' av franskans conducteur 'förare, ledare'. Denne tågbefälhavare klippte med en särskild tång ett hål i resenärernas biljetter. Biljetterna bestod av en bit papp. Mobiler och datorer fanns ännu inte ens i science fiction-filmer, om det ens fanns några sådana. Numera utgörs tågpersonalen av tågvärdar av båda könen. Dessa går genom vagnarna och frågar med en underförstådd uppmaning och med ett vänligt och melodiskt, lätt frågande tonfall: ’Nypåstigna?” Så lockar de fram ett tillåtande pip ur de nypåstigna resenärernas mobiler eller plastkort. Det finns dock fortfarande gammalmodiga resenärer som visar upp en pappersbiljett som de skrivit ut från sin skrivare därhemma. Tågvärdarna har även ansvar för säkerhetskontroll vid avgångar från stationerna, men i ett nytt förslag är tanken att tågvärdar ska arbeta med resenärerna. Lokförarna ska kontrollera säkerheten, något som kan bli svårt om tåget har många vagnar och är över 200 meter långt (Magnusson 2019).

De närmast kommande stationernas namn visas tillsammans med ankomsttider på en display ovanför kupéernas utgångar. Ortnamnen ropas ut i högtalarna, ofta med tillägg som: "Avstigning sker på vänster sida i tågets 
färdriktning" och med upplysningar om anslutande förbindelser. Information av den här sorten ges också i förkortad form på engelska.

Bild 2. Öresundståg håller vid stationen i Alvesta

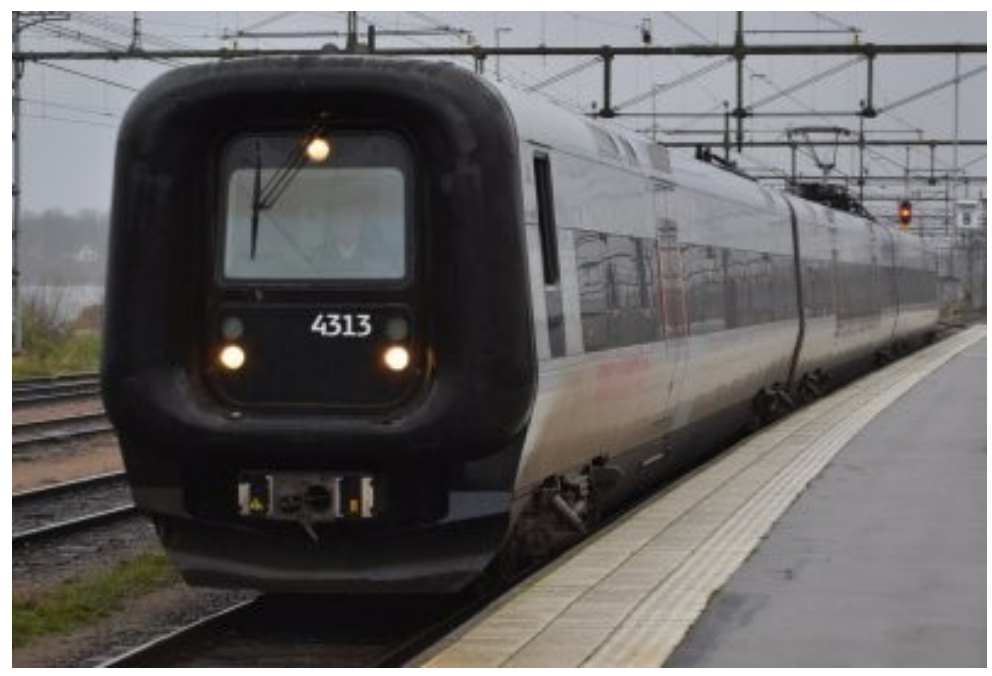

Dessutom förekommer inte så sällan även utrop från lokförare eller tågmästare om tågförseningar. Utropen kan lyda: 'Det är stopp i trafiken på grund av ..." Därefter följer diverse förklaringar till varför tåget stannat. Utom hörhåll för resenärerna finns en uppsjö av ord som ingår i tågbolagens termer för orsaker till att tågen måste stå stilla på spåret. För den lingvistiskt orienterade resenären som inte är så teknikintresserad har de flesta av dessa termer en synnerligen diffus innebörd, men det ohörda budskapet går trots allt fram; det innebär sen ankomst till resans mål.

Men vad betyder alla ord i detta tågens förseningslingo? Signalfel innebär uppenbarligen att något är fel med signalerna på tåglinjen. Signalerna visar var tågen befinner sig och ger lokförarna grönt ljus. Om de inte fungerar som de ska blir det superfarligt för oss resenärer, för tåg kan krocka med varandra på spåren. Så fort signalerna visar rött stoppas trafiken, tills allt är under kontroll igen. Teknisk personal berättar följande: "Många tror att det är ett fel i signalstolpen, men så är det inte alls. Vid ett signalfel visar signalen rött därför att det är fel i anläggningen bortom signalen. Det kan till exempel bero på en trasig växel, ett urspårat tåg, ett ställverk som gått sönder efter ett blixtnedslag eller ett fel i spårledningssystemet som håller reda på tågens position" (Ny teknik 2015). Vagnfel är en klassiker och tas till när något gått sönder i själva tåget. Det kan till exempel vara en dörr som inte stängs ordentligt, och tåget måste tas ur trafik för reparation. Växelfel betyder i de flesta fall att isklumpar faller ner i växeln när ett tåg kör förbi. När växeln sedan ska läggas om så ligger isen i vägen och den fastnar. När växeln inte sluter sig helt, går det inte att få grönt i signalen framför den, och om ett tåg 
ändå kör över så riskerar tåget att spåra ur. Personal måste kanske ut på linjen och hacka bort isen, det bildas kö och förseningarna är ett faktum. Tekniskt fel kan alltid användas när det inte finns något särskilt alternativ för att beskriva vad som inte fungerar.

Ett synnerligen speciellt bekymmer som kan uppkomma i ett tåg är ordningsproblem, vilket innebär att en person i tåget beter sig illa, till exempel genom att slåss eller uppföra sig hotfullt mot andra resenärer eller mot personalen eller genom att inte följa personalens anvisningar om att lämna tåget om resenären saknar biljett. Ett annat och mer fantasieggande hinder för tågen är så kallat spårspring, vilket innebär att obehöriga människor befinner sig i närheten av eller på spåren. Om inte trafiken stoppas riskerar personen att bli påkörd eller elektrifierad via strömskenan. Både ordningsproblem ombord och spårspring innebär i de flesta fall att polis måste kallas till platsen för att inspektera eller ingripa.

Problem som är relaterade till vädrets växlingar finns också för alla fyra årstiderna i förseningsterminologin. På hösten finns lövhalka; denna inträffar när fuktiga löv fastnar på spåren. Då bildas en smet som gör att spåret blir halt, vilket i sin tur leder till att lokföraren måste sänka hastigheten för att inte riskera att tåget glider vidare trots inbromsning. Solkurvor är ett problem som kan uppstå på sommaren då solen ligger på som starkast. Solen gör då att metallen i spåren expanderar och de blir böjda. Blir en sådan böj för stor riskerar tågen att spåra ur. Trafiken stoppas i väntan på avkylning. Rådande väderförhållanden är oftast ett samlingsuttryck för snö och is, och det förekommer på både vintern och våren. Om inte spår och vägar är snöröjda ställs trafiken in tills det är säkert att köra igen.

Luttrade tågpendlare har hört alla dessa utrop till leda. Det senaste tillskottet i tågterminologin upptäcktes vid en perrongvandring i väntan på ett tåg i Eslöv. Ordet är balis, pluralis baliser av franskans balise 'sjömärke'. Balis är en del av tågens telekommunikationsutrustning, och den finns placerad mitt i ett järnvägsspår och är en manick mellan spåren som sänder information till ett passerande tåg om den framförliggande bansträckan. $\mathrm{Om}$ det inte funkar som det ska uppstår ett signalfel, vars innebörd utretts ovan.

\section{Orternas namn och tågens}

Är det sant att ortnamnet Lund är ett s.k. uppkallelsenamn efter London, huvudstaden i England, så som det lär ha påståtts? Nej, svarar de kaxiga lundensarna och hävdar att det tvärtom är London som har uppkallats efter Lund. Namnet betyder i vilket fall som helst 'skogsdunge' och lär ursprungligen ha syftat på några heliga (?) hagtornsbuskar i en lund mellan byarna Valkärra Torn och Östra Torn strax norr om den nuvarande staden.

Efter att på perrongen ha läst och lyssnat oss fram till rätt spår och avgångstid för vår resa till Växjö börjar vår resa mot den första stationen. "Nästa Eslöv och Höör sen!", utropas inte längre av ordvitsiga konduktörer. Ortnamnet Eslöv har efterleden löv som betyder 'arvegods' - inte blad på 
lövträd. Den är en av de äldsta efterlederna i svenska bebyggelsenamn och är vanlig framför allt i Skåne. Men den förekommer också i Halland, Västergötland, Värmland, Småland, Öland och Östergötland och i Danmark. Den ursprungliga formen är forndanskans lef som är besläktad med verbet lämna. Ordet har alltså ursprungligen betytt 'något efterlämnat', och förlederna i lev-namnen är oftast förnamn av gammal, förkristen nordisk typ. De syftar vanligtvis på den person som lämnat egendomen i arv. I det här fallet är dock förleden forndanskans cesir och den syftar på en man som bodde på den lilla ås som finns vid den ursprungliga platsen för byn.

Höör skrevs i en skrift från 1160-talet Hörg. Namnet innehåller ett forndanskt ord hörg som är en form av dialektordet harg som betyder 'stenig mark, stenröse, stengrund'. Bygdens sten, närmare bestämt kalksten, är omtalad, inte minst eftersom den är byggstenen i Lunds domkyrka.

"Hässleholm nästa! Nästa Hässleholm!", förkunnar en röst i högtalaren. Hässleholm har fătt sitt namn efter ett gods (omnämnt som Hesleholm 1563), där stadens äldsta del ligger. Förled i ortnamnet är det dialektala ordet hässle 'hasseldunge', och efterleden är holm 'upphöjning över den kringliggande marken'.

Osby har förleden os- som betyder 'åmynning'. Här syftar ordet på byns läge vid Driveåns utflöde i Osbysjön. Efterleden by betyder helt enkelt 'gård; by'.

Älmhult innehåller trädnamnet 'alm' som ingår i ordet celme 'almdunge'. Det ingår också i namnet IKEA, det vill säga Ingvar Kamprad, Elmtaryd, Agunnaryd. Detta är det akronymt bildade namn som Ingvar Kamprad gav åt sitt numera världsomspännande företag. De två sista bokstäverna står för Elmtaryd, Agunnaryd som är adressen till den gård där han växte upp. Företagsnamnet är alltså bildat till grundarens namn och hans småländska adress på den här jorden.

Alvesta skrevs 1422 Alwasthadha och innehåller troligen ett fornsvenskt mansnamn, Alvir eller Alve. Efterleden är förstås $s t a(d)$, här i betydelsen 'plats'. Näst efter -by är $s t a(d)$ den vanligaste efterleden i gamla svenska sammansatta bebyggelsenamn. "Dyster som en veckopendlare en måndagsmorgon på järnvägsstationen i Alvesta" är en formulering vi tycker oss känna igen. Men vem är upphovsman till uttrycket och hur lyder den ursprungliga formuleringen? Efter en del efterforskningar visar det sig att det är litteraturkritikern och tidningsredaktören Stig Ahlgren (1910-1996) som skriver så om professor Sten Selander (1891-1957), ledamot i Svenska Akademien. I Ahlgrens tappning lyder formuleringen: "lika tråkig som en påstigande i Alvesta" (Sundsvalls Tidning 2009). Formuleringen finns i Arbetartidningen den 9 maj 1941, och den har i mer eller mindre modifierad form citerats och spridits därefter. Emellertid känner vi inte igen oss själva i vare sig tråkighets- eller dysterhetsbeskrivningen, när vi nu odystert inspirerade och i fin form närmar oss vårt pendlarmål med olika språkligheter i tankarna. 
Växjö skrevs Vexio 1286. Namnet har antagligen ursprungligen betecknat Växjösjön. Vägar från fem olika riktningar strålade samman vid Växjösjöns norra spets och har sannolikt haft en avgörande betydelse för att Växjö utvecklats på denna plats, vilket återspeglas i namnet, som bildats av fornsvenskans vaegar och sjö. Växjö var sedan tidig medeltid mötesplats för Tiohärads lagsaga och centrum för folklandet Värend (Larsson 1992:586).

$\mathrm{Nu}$ är vi alltså framme vid vårt pendlarmål och tar bussen till Linnéuniversitetet, men våra tankar reser vidare till universitetets andra del, kuststaden Kalmar vars förled är ett sydöstsvenskt dialektord kalm som betyder 'stenröse, stenanhopning'. Efterleden är en pluralform av arin 'grusö, grusig mark'. Den nutida formen Kalmar slog igenom på 1550-talet, antagligen genom påverkan från tyska namn som Wismar. För dessa och andra ortnamns ursprung och betydelse, se vidare Svenskt ortnamnslexikon.

\section{Pågatåg och Krösatåg}

I enlighet med det gemensamma namnet på en grupp av tåg, Pågatågen, är de flesta enskilda tågen uppkallade efter någon verklig eller fiktiv skånsk påg, pojke. Men en kvinna, Victoria Benedictsson, har fått ge namn åt ett tåg, dock genom sin manliga författarpseudonym, Ernst Ahlgren. För tåg som tas i drift efter 2010 gäller varannan damernas och så småningom kommer tågen $\mathrm{i}$ Skåne troligen att ha uppkallelsenamn efter hälften kvinnor och hälften män. En lista på 49 föreslagna namn finns redan (Åkerlundh 2009). Vi noterar att det inte enbart är verkliga personer som namngivit tågen utan även fiktiva som Hanna från Arlöv, omsjungen av Nationalteatern, och Uarda, en spexig prinsessa från Lund. Den 14 augusti 2013 kom en uppklädd Tiffany Persson från humorserien HippHipp till Lunds station för att döpa ett nytt tåg till just Tiffany Persson. Medierna var på plats och Cecilia Nebel från Sydsvenska Dagbladet intervjuade Tiffany, som uttalar sig på följande sätt:

- För mig är pågatåg könsneutrala, som vissa maskar eller insekter. Dessutom är mina testosteronnivåer högre än på de flesta män. Istället för att ge blod, så tappas jag på testosteron en gång i månaden, inne på MAS ...

Gillar du att åka tåg?

- Jag har inga problem att trängas med andra. Ibland får folk panik av att vara för nära mig. Men det är sällan mitt fel. Om det händer slänger jag av dem i Åkarp. Men pågatågen går ju inte till din hemort Staffanstorp, vad tycker du om det?

- Det är ju synd såklart. Men vi har bra bussar. Och de flesta i Staffanstorp har ju råd att köra bil, till skillnad från Lundaborna. De cyklar mest. De har tubsockor i sandaler också. Otroligt!

Kommer Tiffanys tåg att komma i tid?

- Det hoppas jag verkligen. Eftersom tågtrafiken i Skåne inte kan skylla på snö, som SJ gör, så får de hitta på bra ursäkter. De kan ju inte säga att de var tvungna att stoppa i en tvätt eller letade efter sina nycklar.

Du är känd för att ha ett humör som lätt spårar ur, hur blir det på lördag? 
- Vi får se. Jag gör allt jag kan för att hålla hormonerna på plats, men om någon provocerar mig, så ansvarar jag inte för följderna. (Nebel 2013)

Bild 3. De två Skånetågen Victoria Benedictsson och Ernst Ahlgren vid stationen i Malmö

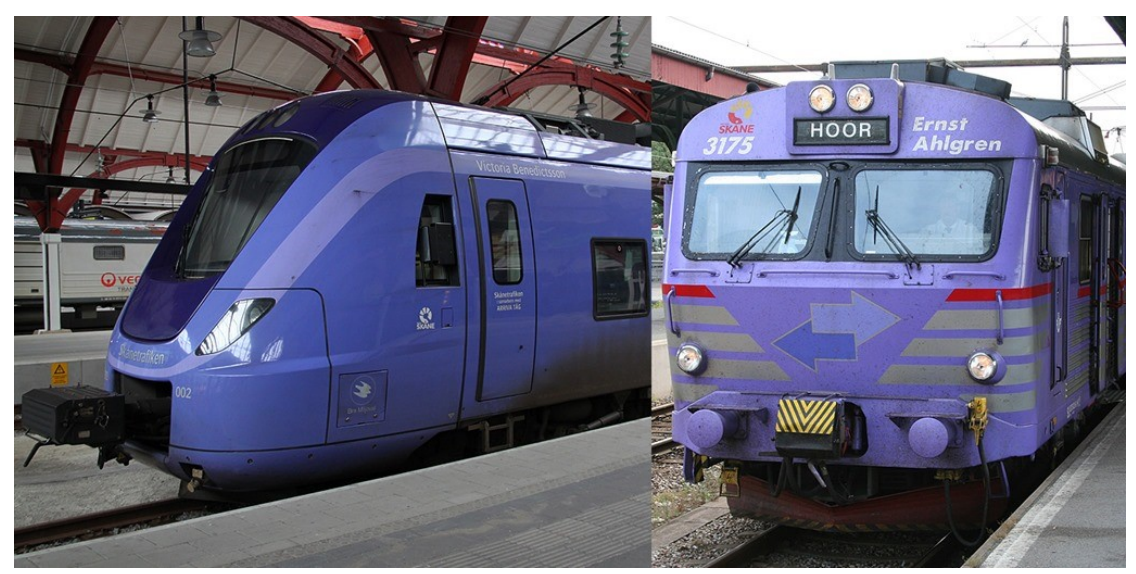

På bild 3 ser vi det gamla tåget Ernst Ahlgren och det nya tåget Victoria Benedictsson, som refererar till samman person, men där det förstnämnda är ett gammalt pågatåg och det sistnämnda ett nytt tösatåg.

Den 1 april 2018 skrev Jonas Nyrén och Daniel Rydén i Sydsvenska Dagbladet under rubriken "Efter metoo: Pågatågen döps om och blir jämställda Skånetågen":

Trycket från upprörda resenärer blev för hårt. Efter 35 år skrotar Skånetrafiken konceptet med Pågatåg. I deras ställe kommer Skånetågen med genusprövade och metoo-säkrade namn. Våra resenärer ska inte behöva känna sig kränkta, säger kommunikationschefen ... Resenärer vittnar om att vissa pågatåg kan kännas kränkande. - Varje morgon Fader Gunnar rullar in på stationen kommer jag för sent till jobbet, säger prästen Anki Jatlén som bor i Ramlösa och arbetar i Malmö. ... Men detta handlar inte enbart om genus, utan också om miljö. Titeln Ålakungen är exempelvis förknippad med ålfisket och har alltid burits av branschens dominerande man. - Ålen är rödlistad, säger Anguilla Pisco på Länsstyrelsens naturvårdsenhet. När vi försöker värna det skånska marina ekosystemet känns det märkligt med ett tåg som heter Ålakungen. Nu döper Skånetrafiken om samtliga tågsätt vilkas namn kan upplevas som kränkande. Uppdraget går till kommittén Tåg för alla, underställd Region Skånes kollektivtrafiknämnd. - Vi gör helt enkelt en genuskoll och metoo-säkring, säger projektledaren Lo Kaj. Hen framhåller att översynen mycket väl kan resultera i att namn på alla historiska personer försvinner som tågnamn - möjligen med undantag av artisten Git Gay. De nya Skånetågen ska målas om i omväxlande rosa, ljusblått och regnbågsfärger. De sistnämnda tågen kommer att förses med icke-binära, könsneutrala namn. Vilka tåg som ska trafikera vilka sträckor bestäms efter en enkät i de trafikerade orterna, där invånarnas insikter $\mathrm{i}$ jämställdhetsfrågor testas ... De områden som behöver möta en ny världsbild 
kommer att få göra det. Jag kan tänka mig att många sträckor på den skånska landsbygden enbart trafikeras av regnbågståg, säger Virke Remmarlöv. (Nyrén \& Rydén 2018)

Artikeln var ett aprilskämt, men bär trots allt på en djupare sanning, nämligen att det trots allt finns fler kvinnliga tåg som trafikerar spåren numera.

Bild 4. Fyra Pågatåg i olika nyanser - verkliga och tänkta för framtida Skånetåg
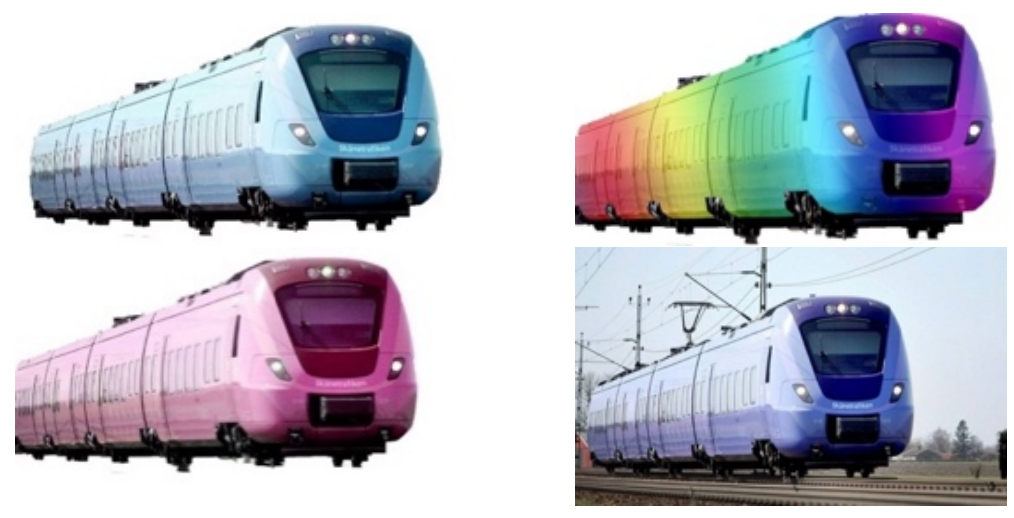

På bild 4 ser vi Pågatåg i tre olika nyanser: rosa, blått och regnbågsfärgat, som skribenterna till artikeln "Efter metoo" tänker sig Skånetrafikens traditionellt lilafärgade Pågatåg.

Krösatågen drivs $\mathrm{i}$ ett samarbete mellan länstrafikbolagen i Blekinge, Jönköping, Kalmar, Skåne, Halland och Kronoberg. På dessa finns det en ombordtidning som heter Lingonet, där man kan läsa om aktualiteter i Småland (http://www.krosatagen.se/lingonet.html). Namnet är en honnör åt Krösa-Maja ('Lingon-Maja'), som ju är en person i Astrid Lindgrens Emil $i$ Lönneberga, en skvallerkäring som berättar hemska historier och använder orden hugaligen (huvalien) och hujedamej (hujedanemej). Dessa ord har därigenom avancerat från småländsk dialekt och fătt plats också i det svenska allmänspråket.

Bild 5. Krösatåg på stationen i Alvesta

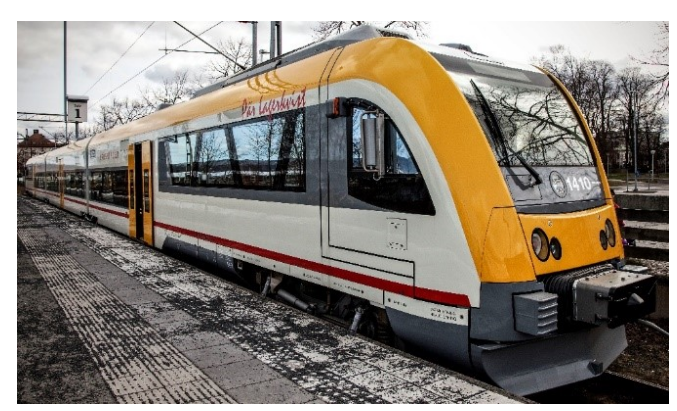


På bild 5 syns ett typiskt krösatåg. Just detta krösatåg är döpt till Pär Lagerkvist, författaren och nobelpristagaren, som växte upp i Växjö och vars barndomshem ligger alldeles intill järnvägsspåret, där tågen stannar.

\section{Vagnarna och kupéerna}

Godsvagn: För några tiotal år sedan fanns det särskilda vagnar för resgods. Resenärer med stora väskor kunde då lämna in sitt bagage till tågpersonal som såg till att detta fick åka med tåget i en särskild vagn. Väskorna polletterades med ett ord som inte längre brukas av nutida resenärer. Numera făr passagerarna i stället släpa på sina tillhörigheter, ofta försedda med hjul och handtag, in i sittvagnarna. Där får de höra upprepningar av högtalarröstens förmaningar, på såväl svenska som engelska: "Föremål som sticker utanför kanten får inte placeras på hatthyllan."

Språkligt orienterade resenärer kan notera att det i tågens vestibuler finns tre alternativt sex sittplatser beroende på om vestibulerna rymmer en toalett eller inte. Ovanför sätena finns två skyltar, en med dansk text och en med svensk. På danska står det: "Forbeholdt kunder med bagage" och på den svenska står det: "Främst för kunder med bagage".

Bild 6. Anvisningsskylt på danska i vestibulen på Öresundståg

\section{Forbeholdt}

kunder med bagage

Bild 7. Anvisningsskylt på svenska i vestibulen på Öresundståg

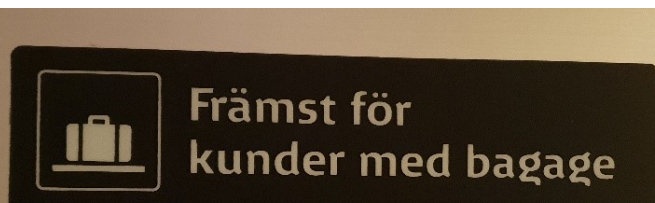

Formuleringarna har olika modalitet, där den svenska uttrycker ett slags inbjudan att sitta ner tills resenärer med stora väskor stiger på tåget och eventuellt gör anspråk på platsen. Den danska ger uttryck för att platsen skulle vara reserverad för resenärer med stort bagage och ingen annan resenär bör därför sätta sig där. Slutligen kan man fundera över varför skyltarna sattes upp över huvud taget. Var det kanske för att undvika ordningsproblem på tåget? 
Rökare: För några tiotal år sedan fanns det särskilda kupéer för rökare och icke-rökare. De skyltar som sorterade passagerarna efter deras nikotinbehov visar att det trots allt inom vissa gränser fanns en viss tolerans för rökare. När vi färdades på sträckan Lund - Växjö i slutet av 1990-talet fanns det en kvinnlig tågvärd som ropade ut: "Nikotinister kan röka utanför tåget i Alvesta, där tåget gör ett uppehåll på 11 minuter”. Vi noterade att det inte var många rökande resenärer som följde tågmästarens omtänksamma uppmaning.

Toaletter: "Upplyft först båda locken mot väggen! Nedlägg därefter det undre locket om så erfordras!' Så stod det på en skylt på toaletterna ännu en bit in på andra hälften av 1900-talet. Männen stod då manligt upp och försökte pricka toaskålen med sin pinkstråle, vilket kunde vara nog så svårt när tåget krängde i sina svängar. När togs den här uppmanande skylten ner? När förändrades mäns kissbeteende? Det är ett historiskt etnologiskt intressant skede i mäns väg från ett upprättstående utomhuskissbeteende mot ett mer renligt och modernt inomhusligt och kvinnligt huksittande. (Att börja stå upp och kissa var för pojkar en sorts markör för inträdet i det vuxna livet som man.)

Bild 8. Skylt med bruksanvisning för gammal tågtoalett

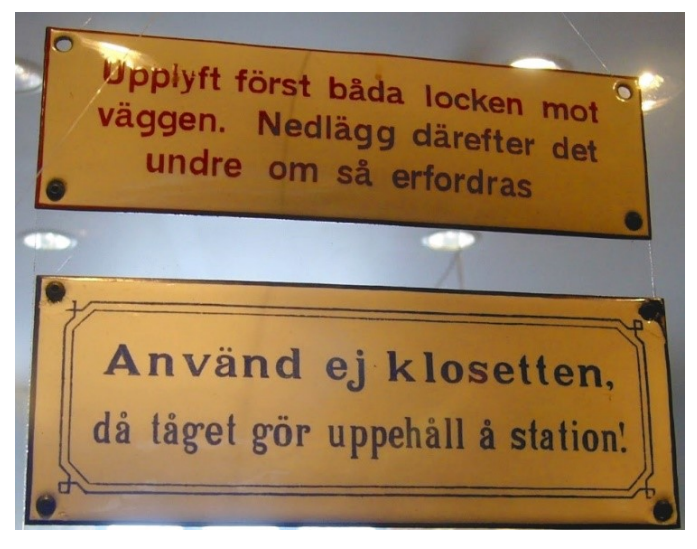

Skylten på bild 8 väcker minnen. Här följer ett utdrag ur en mejlväxling från 2007:

Om man upplyfte båda locken, såg man hur fort marken därnere försvann. Men varför? Vad hände om man bara fällde upp locket och sedan satte sig? Gick det ett larm? Släcktes ljuset? Fick man förstoppning? Anders

De gamla 'fyrkantiga' trälocken var konstruerade med någon sorts spärrhake så att det helt enkelt inte gick att lyfta upp det övre locket utan att samtidigt få med sig det nedre, har jag för mig. Detta var egentligen en utomordentligt fiffig konstruktion. Någon måste ha klurat ut en lösning för att undvika att herrarna skulle skvätta på ringen. Locket och ringen var alltså förbundna med en låsanordning så att de följdes åt när man lyfte på locket. Först när man tryckt fast 
lockets lås mot en hake på väggen lossnade ringen så att den kunde fällas ner separat. Så länge alla toalettbesökare stängde locket efter sig så blev alltså anordningen säker för att herrar inte skulle glömma ringen vid enklare behov. Dock förfelades förstås hela tanken om en besökare som behövt fälla ner ringen inte lade ner locket och sedan efterföljdes av en herre med skvättendenser./HW

Kan väl också sägas att den som satte sig på toaletten (om det var en dam eller ett sådant behov för en herre) och inte först fällde ned det undre locket (ringen) löpte en viss risk att sugas ut genom hålet och hamna på banvallen. Åtminstone kändes det så. Jo, klart att man provat. Jag har alltid gillat att bryta mot SJ:s bestämmelser när det kunnat göras utan risk för upptäckt. /smajlis/

På en resa i Tyskland med museitåg hade man kommit på ett ännu mer infernaliskt sätt att få herrar att utföra även det lilla behovet sittande. Sedan man först upplyft båda locken och påbörjat sitt lilla behov ramlade nämligen det undre ned automatiskt. Det hade dessutom en vass kant. Som en medresenär kommenterade: "Hade jag haft en lite längre så hade jag inte haft den längre". (Tydal 2007)

Tyvärr hör det inte till ovanligheterna att dessa bekvämlighetsinrättningar är ur funktion på tågen. När alla toaletter är obrukbara uppstår ett vagnfel och tåget måste tas ur trafik och pendlarna måste invänta ett nytt tåg eller så måste tåget stanna för en kisspaus, vilket har hänt åtminstone en gång för en tillresande lektor på väg till ett licentiatseminarium i Växjö. Denna paus, som gjordes i Hässleholm, var helt nödvändig för tågresenärerna men fick förstås som följd att tåget blev försenat.

\section{Tyst kupé}

På alla Skånetrafikens tåg finns det tysta kupéer. Där gäller följande mer eller mindre underförstådda regler: "Mobiler ska vara avstängda eller satta på ljudlöst. Samtal ska föras utanför kupén. Musikspelare, dator och andra mediespelare ska användas med hörlurar så att ljud inte läcker ut till omgivningen. Väljer du att resa med barn i tyst kupé, så är det ditt ansvar att barnen visar samma hänsyn".

Bild 9. Skylt i Tyst kupé på Öresundståg

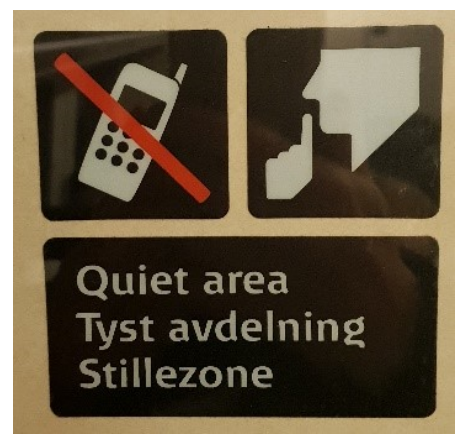


Fredrik i komikerparet Filip \& Fredrik uttalade sig i SJ:s tidning Kupé och hävdade i första numret 2012: "Tyst avdelning är det svenskaste som finns" (Kupé 2012). Påståendet kan förstås diskuteras, men vi kan konstatera att om någon bryter tystnaden kan detta ge upphov till dramatik och konflikt. Ska medresenärerna tysta ner den eller dem som börjar tala med medresenärer eller - ännu värre - med hög röst i mobiltelefon? I vilket tonläge och med vilken röststyrka ska i så fall tystnadens väktare själv bryta tystnaden? Med stumma ilskna blickar? Med hyssjanden? Eller med bryska förmaningar? Vi har sett alla dessa strategier praktiseras på tågen mellan Lund och Växjö med varierande effekt på dem som berörs. I vilket fall som helst kan vi konstatera att Tyst kupé kan vara en naturlig arena för att lätta på trycket för dolda aggressioner.

Ofta är det tyst även i kupéer som inte är försedda med skylten Tyst kupé och ett varnande tystnadsmarkerande pekfinger. De som reser i sällskap i vanliga kupéer samtalar vanligtvis med låg röst. De som reser ensamma talar däremot allt oftare högljutt i sina mobiltelefoner och avskärmar sig från sina medpassagerares ogillande.

Det finns också skyltar som talar om vilka kupéer som är förstaklasskupéer och avsedda för sådana passagerare som har råd att betala extra för en bekväm sittplats bland likasinnade. Det händer att första klass är halvtomt, medan folk får stå och trängas i andra klass. Numera är det ovanligt med särskilda barnkupéer. Småbarnsfamiljer får sitta bland övriga passagerare och försöka hålla styr på sina små, så att de inte stör medresenärerna alltför mycket. En språkintresserad tågresenär kan emellertid roa sig med att tjuvlyssna på samtal mellan vuxna och barn. Här följer ett resultat av ett sådant tjuvlyssnande $\mathrm{i}$ vetenskapens namn.

\section{Tågapåg på pågatåg}

En pendlande språkforskare sitter med papper och penna på tåget från Lund till Växjö och avlyssnar ett språkligt samspel mellan en mamma och hennes son som är i förskoleåldern. De sitter i sätena framför språkforskaren som ivrigt avlyssnar och antecknar deras ord för att studera hur pojken använder sitt språk för att utföra en rad olika handlingar med olika syften: Han pekar ("titta!") och han kommenterar ("en ko"). Men han gör också en hel del annat med hjälp av sitt språk: varnar, anklagar, hotar m.m.

Pojken säger: "Nu är vi i Kalmar!” Men i själva verket är vi bara i Älmhult. Han informerar alltså felaktigt, men kanske i god tro. Kanske försöker han besvärja verkligheten, försöker förändra den så att vi äntligen är framme vid målet för deras resa, Kalmar. Pojken tittar ut genom fönstret och pekar och kommenterar med sina ord: "Bommar!" Han fortsätter att kommentera och tolka vad han ser genom fönstret: "Där går han med sin pappa". Han associerar och kopplar sin iakttagelse till sin egen situation: "Nu är vi på väg till min pappa”. 
Han fortsätter att peka ut vad han ser: "Titta båtar!" Han associerar och fantiserar: "Detta är ett flygplan, ett rymdskepp." Han illustrerar sin fantasi med lekfulla ljud och rytmer: "tam, tamtam tam!" Så avbryts hans fantasier av att han i sin lekfulla iver slår sig i sitt knä. Han ger uttryck för sitt fysiska tillstånd: "Aj!" Men han finner strax tröst genom att gosa med sin mamma: "Mmmm!" Genom sin röst har nu pojken visat att han är just en "han". Det kan man höra trots att han har långt kvar till puberteten. Man kan se att han är i fyraårsåldern och höra att han är från södra Sverige. Efter en stund har han en napp i munnen, och man kan höra bara svårtolkade läten.

Efter en stunds vila börjar han åter prata och ge uttryck för ett fysiskt tillstånd: "Jag behöver bajsa". Man skulle kunna klassa detta som en indirekt talhandling och som ett sätt att förändra den icke-språkliga situationen, d.v.s. förmå mamman att följa sin lille son till toaletten. Efter toabesöket återkommer pojken med förnyade krafter. Han skojar och hotar sin mamma: "Nu skjuter jag dej!" Mamman försöker hindra honom från att klättra på stolsryggen. Han anklagar i frågeform och varnar: "Stoppar du mej?!" Han övergår till att peka, informera och fantisera: "Där är får. Min pappa har bestämt att det fåret får gå på gatan", säger han med beundran i rösten. Han skryter till synes helt omotiverat: "Jag kan klättra i träääd".

Han ber om information: "Är det här tåget stort?" Han prövar absurditeter, leker med ord: "Ett gammalt, nytt tåg." När mamman på nytt försöker hindra honom från att klättra på stolsryggen, förbjuder han: "Du får inte hålla mej!" Han ber om information och ber därigenom också indirekt om service: "Var är nappen?” Han ställer en fråga som innebär en indirekt anklagelse: "Har du ingen godis med dej?!" Och han förstärker anklagelsen genom att uttrycka sin vilja: "Det vill jag ha". Mamman går honom till mötes och ber om ett ställningstagande: "Vilken sort vill du ha?" och pojken svarar genom att uttrycka vilja och val: "Lakrits. En lakritspistol". När lakritspistolen är på plats fantiserar och förskräcker pojken: "Det håller nästan på att rinna ut blodet i min näsa".

Vi är nu framme i Alvesta, tåget backar och pojken informerar om saken och ber om förklaring: "Det går bak. Varför går det bak?” Men han får ingen förklaring och börjar istället fantisera och förändra verkligheten: "Nu är vi hos Martin". Han relaterar till en tidigare händelse och uttrycker sin vilja: "Nu vill jag ha en till lakritsbit". Och i samma andetag förvarnar han om vad som kommer att ske lite senare: "Sen vill jag ha en till". Han inser nog att han har en god förhandlingsposition i det här ärendet, för mamman vill inte ta någon strid med hänsyn till medpassagerarna.

Pojken klättrar på stolen och mamman vädjar, befaller i frågeform: "Erik, kan du sätta dej ner nu!?" Men pojken uttrycker egen vilja, som innebär olydnad: "Nä, jag vill sitta högt upp". Mamman vänder sig till medresenärerna. Dessa försäkrar att det inte gör något om pojken sitter uppe på ryggstödet. Pojken härmar sin mamma: "Gör det något om han sitter här uppe?" Han börjar provocera och leka med ord: "För jävla typ. Jävla tåg, jävla 
tåget". Mamman bemöter honom genom att straffa och hota: "Jag lyssnar inte på dej om du pratar så". Men pojken visar likgiltighet: "Jävla tåget" och tröstar sig själv: "Aurrrrrr. Mormor lyssnar på mej." Han lägger sin kind mot mammans och viskar högt: "Jag ska viska en sak i ditt öra". Han visar förtroende och verkar be om försoning. Men efter en stunds vila och eftertanke väcker han liv i konflikten igen. Han hotar: "Mamma! Sen när du är gammal, och jag inte är gammal, då ska jag skjuta dej. Säja jävlar först. Sen ska jag skjuta dej”. Så faller pojken. Han slår sig och kryper gråtande upp i mammans famn. Mamman tröstar: "Så ja! Såååja!" (fritt citerat efter Einarsson 2013:99). Nu är tåget i Växjö, och då är alla harmoniska. Tåget fortsätter mot Kalmar med nya medpassagerare som får lyssna på den spännande fortsättningen av samtalet mellan mamman och den lille tågapågen.

Vi konstaterar att pendlande språkforskare kan ägna sig åt olika reflektioner för att hålla sig i lingvistisk form under sina tågresor mellan Lund och Växjö tur och retur. Resor kan vara språkligt och ibland litterärt bildande på de mest skiftande vis, där tal, skrift och bild stimulerar en språkvetare att reflektera över språkliga fenomen och ords och uttrycks betydelse och hur människor samspråkar med varandra på resan. Språket på spåret ger mål och mening åt vår färd.

\section{Litteratur}

Einarsson, Jan (2013). Språket och språkarna. 1. uppl. Lund: Studentlitteratur.

Kupé, SJ Ombordtidning (2012). Nummer 1, 2012. (Hämtad 2018-12-31: http://www.e-magin.se/paper/4f5x5vxn/paper/72\#/paper/4f5x5vxn/1).

Larsson, Lars-Olof (1991). Växjö genom 1000 år. Stockholm: Norstedt.

Lingonet (u.å.). (www.krosatagen.se/lingonet.html).

Magnusson (2019). "Anklagelse om maskning väckte lokförarnas ilska". I Sydsvenska Dagbladet (Hämtad 2019-01-9, publicerad 2019-01-07: https://www.sydsvenskan.se/2019-01-07/anklagelser-om-maskninguppror-lokforarna-pa-pagatagen).

Nebel, Cecilia (2013). "Tiffany Persson inviger tåg”. Sydsvenska Dagbladet (Hämtad 2018-12-31, publicerad 2013-08-14: https://www.sydsvenskan. se/2013-08-14/tiffany-persson-inviger-tag).

Nyrén, Jonas \& Rydén, Daniel (2018). 'Efter metoo: Pågatågen döps om och blir jämställda Skånetågen”. Sydsvenska Dagbladet (Hämtad 2018-12-30, publicerad 2018-04-01: https://www.sydsvenskan.se/2017-04-01/eftermetoo-pagatagen-dops-om-och-blir-jamstallda-skanetagen).

Ny teknik (2015). (Hämtad 2018-12-30, publicerad 2018-01-22: https://www.ny teknik.se/fordon/trafikverket-har-ar-orsakerna-till-sena-tag-6894428).

Sundsvalls Tidning (2009). "Sympatisk person med märkliga tycken". Kulturredaktions recension av Bengt Landgrens bok om Sten Selander lyrik och litteraturkritik 1916-1957, först publicerad i Arbetartidningen 1941-05-09. 
Svenskt ortnamnslexikon (2016). Wahlberg, Mats (red.), Andra reviderade upplagan Uppsala: Institutet för språk och folkminnen.

Tydal, Tomas (2007). (Hämtad 2018-12-30, publicerad 2007-01-27: http://www. tydal.nu/).

Åkerlundh, Ewy (2009). "Pågatågen har fått sina namn". Sydsvenska Dagbladet. (Hämtad 2018-12-30, publicerad 2019-06-01: https://www.sydsvenskan. se/2009-06-01/pagatagen-har-fatt-sina-namn).

\section{Förteckning över bilder}

Bild 1. Lunds östra station. Foto: Anton Holmquist \& Pauline Gyllengam Soasta (https://commons.wikimedia.org/w/index.php?curid=3065692). Hämtad 2018-12-28:

https://sv.wikipedia.org/wiki/Lunds_centralstation\#/media/File:Lunds_centralst ation2007.jpg).

Växjö station 2018 hämtad 2019-01-10:

https://www.facebook.com/477719005596479/photos/pcb.1698679340167100/ $1698678250167209 /$ ?type=3\&theater).

Bild 2. Öresundståg håller på stationen i Alvesta. Foto: Anton Andersson.

(Hämtad 2019-01-10, publicerad 2014: http:/www.lokstallet.n.nu/x31/x32).

Bild 3. De två Skånetågen Victoria Benedictsson och Ernst Ahlgren vid stationen i Malmö (Hämtad 2019-01-10, publicerad 2013-03-03:

https://arskortguldsj.wordpress.com/2013/03/03/vad-har-dessa-tv-pgatggemensamt/).

Bild 4. Fyra Pågatåg $i$ olika nyanser - verkliga och tänkta för framtida Skånetåg (Hämtad 2018-12-30, publicerad 2018-04-01:

https://www.sydsvenskan.se/2017-04-01/efter-metoo-pagatagen-dops-om-ochblir-jamstallda-skanetagen).

Bild 5. Krösatåg på stationen i Alvesta (Hämtad 2019-01-10: https://www.rtforum.se/article/view/591960/gratis_krosatag_i_sydvast).

Bild 6. Anvisningsskylt på danska i vestibulen på Öresundståg. Foto: Gunilla Byrman, 2018.

Bild 7. Anvisningsskylt på svenska $i$ vestibulen på Öresundståg. Foto: Gunilla Byrman, 2019.

Bild 8. Skylt med bruksanvisning för gammal tågtoalett. (Hämtad 2019-01-10: http://varahusbilsresor.blogspot.com/2013/04/sveriges-officiellajarnvagsmuseum.html).

Bild 9. Skylt i tyst kupé. Foto: Gunilla Byrman, 2018. 